\title{
Kinematic linkage between internal zone extension and shortening in more external units in the NW Alps
}

\author{
J. WHEELER ${ }^{1}$, S. M. REDDY ${ }^{2} \&$ R. A. CLIFF ${ }^{3}$ \\ ${ }^{1}$ Department of Earth Sciences, The University of Liverpool, Liverpool L69 3BX, UK \\ ${ }^{2}$ Tectonics Special Research Centre, Department of Applied Geology, Curtin University of Technology, Perth, \\ WA 6845, Australia \\ ${ }^{3}$ Department of Earth Sciences, The University of Leeds, Leeds LS2 9JT, UK
}

\begin{abstract}
In the Alps a major extensional shear zone unroofed eclogites in its footwall from $30 \mathrm{kbar}$ to c. $10 \mathrm{kbar}$, implying of the order of $60 \mathrm{~km}$ of relative vertical movement in the period $45-36 \mathrm{Ma}$. The horizontal component of divergence was of the order of $100 \mathrm{~km}$. We use the foreland basin sedimentary record to prove that the extension was contemporaneous with thrusting in units structurally beneath the eclogites (the Briançonnais and/or External Zones). This thrust-related convergence during that time period was of the order of $44-56 \mathrm{~km}$ and therefore of the same order of magnitude as internal zone divergence. Extension may have been driven by internal density contrasts. Buoyant continental crust underneath the mafic eclogites, or dense subducted slab offset from the orogen, can induce extension. Any dynamic model must account for the comparable magnitudes of extension and shortening in adjacent parts of the orogen: relative plate motions in the period 45-36 Ma played a subsidiary role.
\end{abstract}

Keywords: Alps, extension, kinematics, eclogite, foreland basins.

Horizontal extension in the internal zones of convergent orogens is now recognized as a key process near plate boundaries. The proposal of plausible driving forces, the observation of extensional earthquakes in high plateaux, and of normalsense metamorphic breaks and extensional structures in older belts have all contributed to our understanding in the last 15 years (Platt 1987; Molnar \& Lyon-Caen 1988). It remains difficult to quantify the magnitude and geometry of extension in modern and ancient orogens, and its relationship to shortening, and this hinders discrimination between different driving forces. In this contribution we demonstrate the kinematic links between extension and shortening in a relatively well-constrained orogen, and show how this restricts possible dynamic models. Past extension in mountain belts can be established from field evidence of fabrics, larger-scale structures and metamorphic breaks (Wheeler \& Butler 1994). Timing information must be used in addition to distinguish between different dynamic models. For example, consider a dynamic model in which overall plate divergence induces tensional stresses and therefore extension everywhere (Andersen et al. 1991). If thrusting is present in such a system then it must be of different age. Horizontal divergence of points at some positions with simultaneous shortening elsewhere can result from e.g. gravity spreading (Dewey 1988), expulsion of 'slivers' of buoyant material (Chemenda et al. 1995), and slab roll-back (Royden 1993): all of these result ultimately from density contrasts.

The Alps are uniquely well-suited for study of the effects of orogenic extension. Extensive eclogite facies units are present; mineral assemblages indicate burial depths of up to $100 \mathrm{~km}$, so their presence at the surface proves lithosphere-scale vertical movements. Such movements have been shown in one transect to be due to horizontal extension (Wheeler \& Butler 1993; Reddy et al. 1999). In addition transects from one plate to the other are completely exposed, and the timings of events in internal and external zones are better constrained than those in older orogens.

\section{Context of Alpine extension}

We focus on a NW-SE transect running from NW Italy through the Franco-Swiss border region (Fig. 1). In the Mesozoic, the Piemonte ocean separated the northern (European) and southern (Adriatic) continents: the ocean was closed by a SE-dipping subduction zone in which the Adriatic plate overrode the ocean. In the external zones, European continental basement, Mesozoic cover and synorogenic sediments have been intensely shortened. Passing SE, structurally higher tectonic internal zones are metamorphosed at greenschist to eclogite facies. The Briançonnais Zone contains basement and Mesozoic cover: it may have been connected to the European margin or separated by a minor ocean (Lemoine \& Trümpy 1987). The Internal Basement Massifs are similar, but have an eclogite-facies history. Both Briançonnais and Internal Basement Massifs lie structurally beneath the Zermatt-Saas unit which contains ophiolitic material, remnants of the Piemonte ocean. It contains many eclogite-facies assemblages indicating high pressures (HP) of up to $20 \mathrm{kbar}$ and, at one locality on our transect (Lago di Cignana, Reinecke 1991), coesite-bearing eclogites at c. 30 kbar implying burial to $c .100 \mathrm{~km}$ before exhumation. Peak assemblages have been dated at $40.6 \pm 2.6 \mathrm{Ma}$ from $\mathrm{Sm} / \mathrm{Nd}$ on garnet (Amato et al. 1999). Zircon containing rutile is dated at $44.1 \pm 0.7$ (Rubatto et al. 1998); this could still be prograde, so the garnet age is taken here as an indicator of the time of peak pressure. Ultra-high pressure (UHP) assemblages also occur $17 \mathrm{~km} \mathrm{NE}$ of the transect (Barnicoat 1996). Both occurrences are enveloped by HP eclogites. It is not known whether the HP and UHP rocks belong to separate tectonic units, or the 

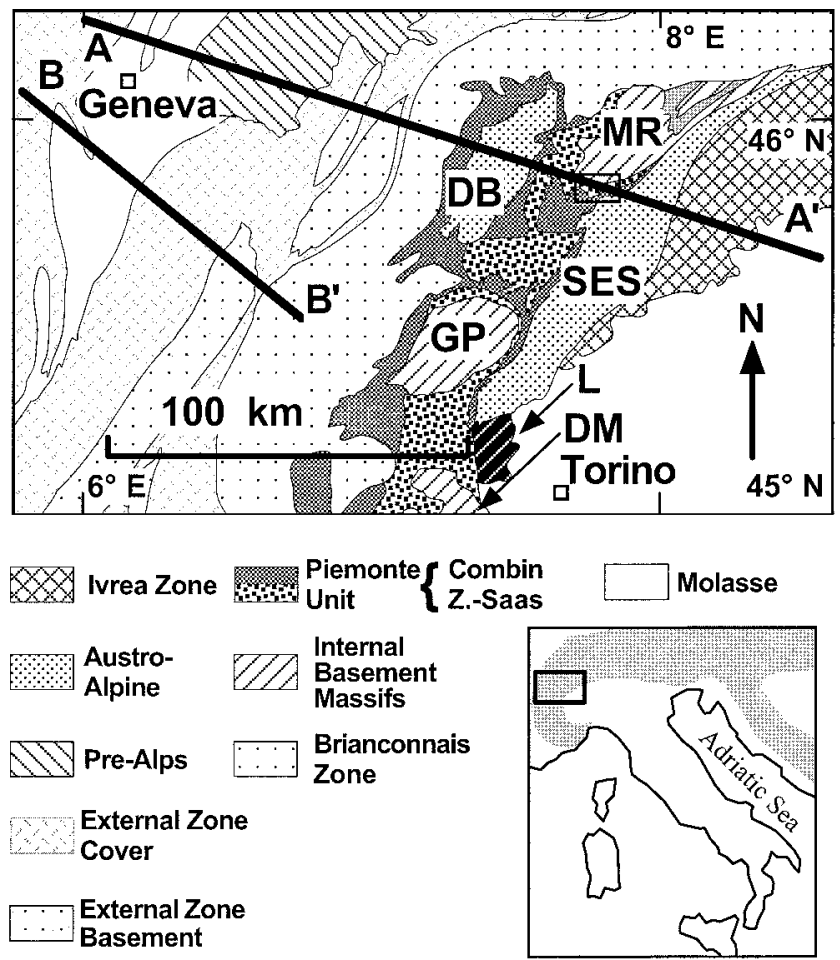

Fig. 1. Regional setting of the Western Alps. AA' is the study transect, BB' is the Annecy foreland basin transect shown in Figure 3. The lower part of the Piemonte (the Zermatt Saas unit) and the Internal Basement Massifs contain eclogite-facies assemblages. The upper part of the Piemonte (the Combin unit) is a greenschist-facies extensional shear zone which passes immediately beneath the Austroalpine units. DB, Dent Blanche klippe; SES, Sesia unit; L, Lanzo peridotite body; MR, Monte Rosa unit; GP, Gran Paradiso unit; DM, Dora Maira unit. Box indicates detailed study area of Reddy et al. (1999).

HP rocks represent a pervasive retrograde overprint of UHP rocks. Structurally above the Zermatt Saas unit is the Combin unit, which consists of calcareous schists and metabasites at greenschist facies: albite is common in these rocks, constraining pressure to be quite low during deformation, though the $\mathrm{Si}$ content of celadonite suggests pressures up to $9 \mathrm{kbar}$. Therefore there is a large metamorphic break (from $30 \mathrm{kbar}$ to $<10$ kbar) between the two units (Reddy et al. 1999).

Mapping and structural analysis shows that the Combin unit is contained within a top-SE directed extensional shear zone (the Gressoney Shear Zone). This passes beneath the structurally higher continental material of the Adriatic plate (the Sesia zone) and affects the lowermost portion of that unit. The Gressoney Shear Zone does not re-emerge further SE. Age of movement has been deduced from $\mathrm{Rb}-\mathrm{Sr}$ mineral isochrons. All dated samples have strong greenschist facies foliation and only one generation of mica, implying pervasive dynamic recrystallization during deformation below the $\mathrm{Rb}-\mathrm{Sr}$ closure temperature in micas. This should equilibrate the ${ }^{87} \mathrm{Sr} /{ }^{86} \mathrm{Sr}$ isotope ratios in different minerals. In confirmation, $\mathrm{Rb}-\mathrm{Sr}$ dates are reproducible from different samples from the same structural setting, i.e. from what appears in the field to be the same foliation. Some fabrics in the Gressoney Shear Zone show low-angle cross-cutting relationships. $\mathrm{Rb}-\mathrm{Sr}$ dates agree with the relative ages of fabrics deduced from field mapping (Reddy et al. 1999). Together these arguments mean that we

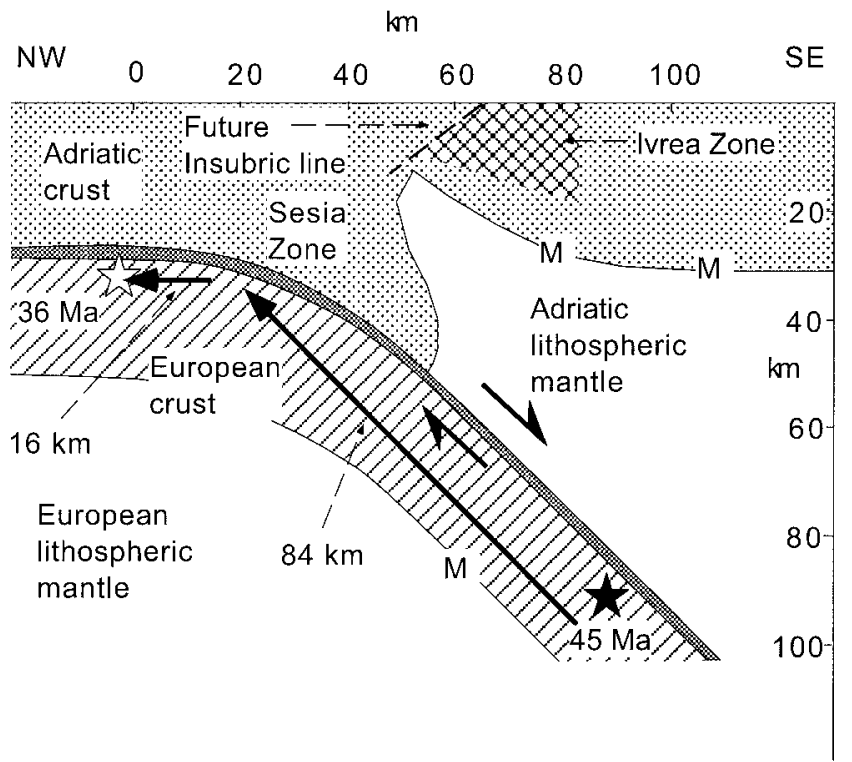

Fig. 2. Diagram showing estimate of internal zone extension magnitude. Ornaments correspond broadly to those of Figure 1, but the Zermatt-Saas unit (now only c. $2 \mathrm{~km}$ thick) is not distinguished from European crust. The Combin unit (dark ornament, roughly equivalent to the Gressoney Shear Zone) has its thickness exaggerated for clarity; it is now $c .1 \mathrm{~km}$ thick, though this may itself represent attenuation of an originally thicker unit. The Gressoney Shear Zone underwent extensional movement, unroofing eclogite-facies rocks (and UHP rocks marked by star) from $90 \mathrm{~km}$ at $45 \mathrm{Ma}$ to $30 \mathrm{~km}$ at $36 \mathrm{Ma}$. We postulate that a mantle wedge was originally above the UHP rocks. There is no evidence for substantial unroofing of the Austroalpine hangingwall (Sesia zone, stippled) during this time interval (the eclogite-facies rocks in the Sesia zone were already exhumed to greenschist facies by $45 \mathrm{Ma}$ ). M, Moho.

interpret our $\mathrm{Rb}-\mathrm{Sr}$ dates as deformation ages. The Gressoney Shear Zone was thus in operation from $44.6 \pm 0.4 \mathrm{Ma}$ to $36.5 \pm 0.4 \mathrm{Ma}$. The oldest age overlaps with the zircon age for the coesite-bearing eclogites and is slightly older than the garnet age (see above). The youngest Gressoney Shear Zone fabrics truncate greenschist-facies folds (overprinting eclogitefacies assemblages) in the footwall. The extensional Gressoney Shear Zone was moving throughout the time period from UHP eclogite facies to greenschist facies in the footwall; the hanging wall was at greenschist facies throughout this period. Therefore movement on the Zone was the main structure responsible for unroofing the footwall eclogites from $30 \mathrm{kbar}$ to $10 \mathrm{kbar}$. Reddy et al. (1999) showed that the Gressoney Shear Zone unroofed the HP eclogites; the new date for the UHP eclogites (Amato et al. 1999) allows us to extend our argument to include their unroofing, even though their detailed relationship to the HP rocks remains to be clarified. In subsequent discussion we round the oldest and youngest ages recorded from the Gressoney Shear Zone to 45 and $36 \mathrm{Ma}$ to yield conservative estimates for the rate of eclogite unroofing.

\section{Horizontal magnitude of Alpine internal zone extension}

The vertical component of relative movement across the Gressoney Shear Zone was $c$. $60 \mathrm{~km}$. Figure 2 shows a simple model for the geometry in which the $<2 \mathrm{~km}$ thick Gressoney Shear Zone is discussed as if it were a single normal fault with 
constant slip, a viable approximation on the scale of the Alps. The Zone would have been subhorizontal over its present exposed span during movement, for the following reasons. (1) Rocks in the hanging wall of the Gressoney Shear Zone are all remnants of the southern continent (Adria) and are at greenschist facies from the NW edge of the Dent Blanche klippe to NW edge of the Sesia zone (Compagnoni et al. 1977), a present day horizontal distance of $45 \mathrm{~km}$. The Sesia zone contains eclogite-facies rocks structurally above (and SE of) its NW margin, but these are significantly older than the Zermatt Saas eclogites and the Gressoney Shear Zone (Inger et al. 1996) so are not discussed further here. There is no evidence for major lateral pressure variations in the hanging wall while the Gressoney Shear Zone was active, implying that it was subhorizontal over this exposed portion. (2) The oldest preserved rocks in the Gressoney Shear Zone (45 Ma) are greenschistfacies assemblages, as are the youngest. Consider the rocks that would be present in a dipping shear zone in which different strands had operated at different times. Early sheared rocks might be carried up passively between younger active strands of the shear zone, or redeformed to give younger deformation ages and lower pressures from recrystallized assemblages. Therefore 'old' tectonized rocks would be from deeper levels than younger ones. The absence of originally deep rocks within the Gressoney Shear Zone suggests an important component of subhorizontal movement. We conclude that, whilst the Gressoney Shear Zone must have had an original dip to the SE of its present outcrop, this dipping portion curved into a subhorizontal structure passing NW (Fig. 2). If the dipping portion were vertical, the horizontal component of extensional displacement (HED) would be $60 \mathrm{~km}$. A more plausible dip of $45^{\circ}$ leads to an estimate of $84 \mathrm{~km}$ of displacement on the dipping portion of the Zone, plus another $16 \mathrm{~km}$ to move the Cignana coesite locality to its present position (Fig. 2). Steeper original Gressoney Shear Zone dips would imply lower displacement estimates, but the HED at the structural level of the Zone was of the order of $100 \mathrm{~km}$. This was accomplished between 45 and $36 \mathrm{Ma}$, giving an average HED rate of $11 \mathrm{~mm} \mathrm{a}^{-1}$.

\section{Comparison with more external zone evolution}

In order to clarify the dynamics of extension, we must determine whether it was synchronous with any folds and thrusts further NW in the Briançonnais or external zones of the Alps (Coward \& Dietrich 1989) (Fig. 1). Relative plate movements are not well-enough constrained to be diagnostic. We therefore consider direct dating of thrusts, ages of related sediments and finally the foreland basin record.

(1) Folds and thrusts are present further NW in the external zones (Coward \& Dietrich 1989). Ages of thrusts may be constrained by direct dating of thrust fault rocks, but this is difficult at low grades. Freeman et al. (1998) report Rb-Sr geochronological studies from south of our transect indicating early top-NW ductile thrusting at $45 \mathrm{Ma}$ in the Briançonnais domain, and later foreland-migrating top-NW thrusting in the period 34-27 Ma. The extensional episode we report here only just overlaps in time with these thrust events, so we do not consider this reliable evidence for contemporaneity.

(2) Alternatively thrust timing is bracketed by the ages of rocks involved in thrusts and by sediments demonstrably deposited after thrusting ceased. The structurally high klippen of the Prealps (Mosar et al. 1996) contain sediments as young

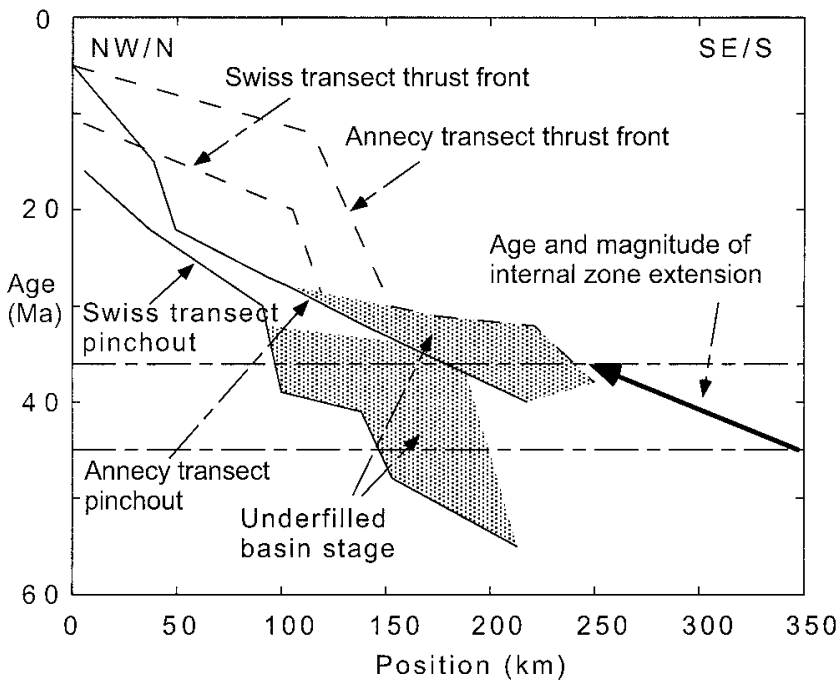

Fig. 3. Chronostratigraphic diagram showing migration of the Alpine foreland basin on the Annecy transect and Swiss transects, and the magnitude and timing of internal zone extension (Sinclair 1997). For each transect, the position of the pinchout and the thrust front are shown. The two transects are superimposed to show that migration rates were broadly comparable. Horizontal lines mark the start and end times of movement on the Gressoney Shear Zone, and the thick arrow indicates its HED. Note how that thick arrow mimics the Annecy transect pinchout migration, showing that the rates of HED and of pinchout migration are broadly comparable.

as Bartonian (the Flysch Medianes, Lutetian-Bartonian, 46-39 Ma). These sediments are interpreted as having been deposited on the Briançonnais basement: sedimentation therefore continued during the 'early' overshear in that unit. Pebbles from the Prealps are found in molasse of Chattian age (28-23 Ma). This brackets the age of thrusting at this structural level, but again does not prove synchroneity with extension. Olistostromes ('wildflysch') deposited above flysch may indicate the proximity of a thrust front (Sinclair \& Allen 1992). Near the target transect, these are present in the normal limb of the Morcles nappe and are dated at $34 \mathrm{Ma}$ in age; structurally higher and earlier Priabonian wildflysch in the Ultrahelvetic nappes is 36-39 Ma. In Eastern Switzerland wildflysch overlies the Taveyannaz sandstone and may be as young as $36 \mathrm{Ma}$. The Taveyannaz sandstone itself shows lateral thickness variations suggesting a thrust-top ('piggyback') basin setting Eastern Switzerland (Sinclair 1992), and the equivalent Annot sandstone in Provence shows similar geometry. None of this evidence provides proof that thrusting was contemporaneous with extension.

(3) If the migration of foreland basin sediment patterns is caused by thrust front advancement then this migration is a proxy for thrusting history. All around the Western Alpine arc, foreland basin edges advanced across the European margin during the Eocene and Oligocene (Pfiffner 1986; Sinclair 1997), this continuous advance being dated by biostratigraphy. Restored sections (Sinclair 1997) show $56 \mathrm{~km}$ of basin margin migration in the period 45-36 Ma in Eastern Switzerland and at least $44 \mathrm{~km}$ along the Annecy transect in France (Fig. 3). Sediments as old as $45 \mathrm{Ma}$ are not found in the Annecy section, hence this estimate is a minimum. The values for post-Mesozoic shortening are minima, as are consequent onlap estimates, because no correction was made for layer parallel shortening. The basin margin advance is explained in terms of 
a continuously advancing thrust load, the migration of load causing the migration of elastic flexure in the European plate. If the load were to maintain its shape, and all other factors remain the same, then the margin advance rate would equal the load advance rate. However, other factors including elastic parameters and basin fill volume make the link more subtle.

(a) A decrease in elastic thickness through time will cause a decrease in foreland basin width (Beaumont 1981) even if the load remains static. Conductive heating and consequent weakening of the flexed plate due to burial could cause this decrease in elastic thickness, but it would cause a migration of the basin margin towards the orogen for which there is no evidence. Cooling of the plate would cause an increase in basin width but we see no reason to expect this to be happening during the time period addressed. Basin width will also decrease through time in a viscoelastic response (Quinlan \& Beaumont 1984), again, this cannot explain the observed migration.

(b) A separate consideration is that of basin fill volume. Basin width increases as average fill density increases, for instance in a static period after a stage of shortening (Flemings \& Jordan 1990). In the Alpine basin, water in the 'underfilled' stage is superceded by sediment fill to near sea level or above during the Oligocene (Sinclair 1997). However, the sedimentary record shows that the basin was underfilled through the time period of internal zone extension.

Of the three lines of argument given above, we consider the foreland basin migration to be the strongest evidence for thrust activity. Foreland migration of the basin edge was related to foreland-directed migration of the orogenic load. In the absence of any other deformation, SE-directed extension would thin and decrease any orogenic load. We conclude that extension in the internal zones was contemporaneous with shortening in units NW of, and structurally lower than, the Piemonte zone, either in the external zones proper or in the Briançonnais zone.We will assume that to a first approximation the migration of the basin reflects the displacement of the SE end of a thrust load of fixed shape. This displacement is not necessarily the same as the migration of the thrust front (as Figure 3 shows, thrust front and pinchout migration rates may be different), but the latter is related more to local thrust propagation and displacement rates. Our aim is to obtain an indication of how thrusting compares with extension, for which precise values are not necessary. A minimum (for reasons given above) of $44 \mathrm{~km}$ of displacement of thrust load along the transect under discussion occurred whilst $100 \mathrm{~km}$ of extension was underway in the internal zones. Clearly the extension was not minor in comparison to thrusting. Even if the amount of thrusting is underestimated by a factor of 2 , then it still only balances, rather than dominates, extension. We conclude that extension was not a 'second-order' effect, but was a major feature of Alpine evolution in the late Eocene.

\section{Speculation on the dynamics of extension}

Our key conclusion is kinematic: we have shown that, in the Eocene, a body of rock including the Piemonte eclogites was bounded by extensional shear above and thrusting below. In Figure 4 we simplify the thrusting to a single surface, and indicate some alternative geometries. It is likely that thrusting and extensional structures both merged with the subduction zone at deep levels, otherwise, if both had independent deep continuations, this would imply that central rock body belonged to a separate microplate. We cannot tell whether the a
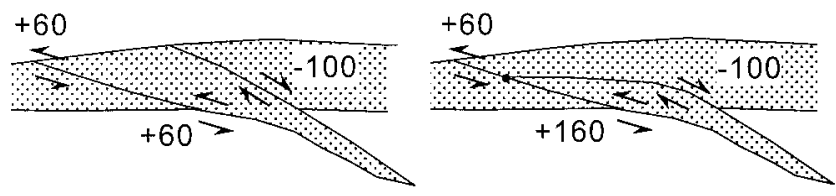

Fig. 4. 'Sliver' (a) and 'Pip' (b) models for linkage of thrusting and extension. Numbers show displacement in $\mathrm{km}$ on major shear zones, taking a nominal $60 \mathrm{~km}$ of zone thrusting during the time period of internal zone extension.

thrusting and extension merged updip (thus bounding a 'pip' of rock) or whether they reached the palaeosurface in different positions (thus bounding a 'sliver'). Whatever the details of geometry, contemporaneous shortening and extension cannot be explained solely by relative movements of two plates. Negative density contrast provides one possible drive for slivers such as that of Figure 4 to move upwards (Platt 1987; Chemenda et al. 1995), a specific example being the DabieHong'an UHP rocks of China (Hacker et al. 2000). The mafic Zermatt-Saas eclogites are dense, but lie above continental rocks of the Monte Rosa unit which are partly eclogite facies (16 kbar, Chopin \& Monié 1984) yet still less dense than mantle. The mafic eclogites could have been carried upwards on the back of these buoyant rocks. It is not clear, however, whether the Monte Rosa unit was buried deeper than $16 \mathrm{kbar}$ and retained metastable assemblages, or when the present contact with Zermatt-Saas rocks was established. Other continental units, not currently exposed, may have been involved, at depth, down-dip or along strike (cf. Hacker et al. 2000). Alternatively, density contrasts elsewhere in the orogenic system gave rise to tensional stresses in the internal zones. For example the presence of a deep, dense slab offset from the centre of a mountain belt can give rise to simultaneous tension and nearby compression (Bott 1990). Dynamic modelling to test these possibilities is in progress.

If density contrasts are playing a part, then plate convergence is not an essential part of the process during the time period in question. The broadly radial pattern of external zone thrusting in the Alps has long been problematic, because of its incompatibility with a single plate convergence vector: strain must be partitioned. Platt et al. (1989) argued that the radial pattern suggested body forces generated by local topography of the thrust wedge, superimposed on overall plate convergence. We propose a modification of this idea, in which the body forces are due not to topography but to the subduction of buoyant continental margin slivers and act locally up-dip in the sliver. The initial geometry of the subducted continental margin could be produced by a single subduction direction but, if the geometry were arcuate, buoyancy forces would cause movement of material locally perpendicular to the subduction zone. Thrusting may be kinematically linked to uprise of internal zone slivers not just on the transect detailed here but on others, which would explain not only the radial pattern of thrusting but also the presence of eclogite-facies rocks structurally below lower-grade material in various positions around the Alpine arc.

\section{Summary}

We emphasize that extension in the internal zones of the Alps on at least one transect was a major contribution towards external zone shortening in the late Eocene. Plate convergence 
on its own cannot explain this; internal density contrasts may have governed evolution at this time. Similar kinematic and dynamic linkages (not necessarily all of the same age) around the Alpine arc could explain the broadly radial pattern of thrusting in the Western Alps. Internal zone extension is a first-order feature of Alpine evolution in the Eocene and may prove to be equally important in other mountain belts.

This work was funded by NERC grant GR3/8606. We thank R. Butler for comments. This paper is TSRC Publication No. 128.

\section{References}

Amato, G.M., Johnson, C.M., Baumgartner, L.P. \& Beard, B.L. 1999. Rapid exhumation of the Zermatt Saas ophiolite deduced from high precision $\mathrm{Sm} / \mathrm{Nd}$ and $\mathrm{Rb} / \mathrm{Sr}$ geochronology. Earth and Planetary Science Letters, 171, 425-438

Andersen, T.B., Jamtveit, B., Dewey, J.F. \& Swensson, E. 1991. Subduction and eduction of continental crust: major mechanisms during continentcontinent collision and orogenic extensional collapse, a model based on the south Norwegian Caledonides. Terra Nova, 3, 303-310.

BARNICOAT, A.C. 1996. Dolomite breakdown under ultra-high-pressure conditions in the Allalin gabbro of SW Switzerland. EOS Abstracts, F762.

Beaumont, C. 1981. Foreland basins. Geophysical Journal of the Royal Astronomical Society, 65, 291-329.

Botт, M.H.P. 1990. Stress distribution and plate boundary forces associated with collision mountain ranges. Tectonophysics, 182, 193-209.

Chemenda, A.I., Mattauer, M., Malvieille, J. \& Bokun, A.N. 1995. A mechanism for syn-collisional rock exhumation and associated normal faulting: Results from physical modelling. Earth and Planetary Science Letters, 132, 225-232.

Chopin, C. \& MoniÉ, P. 1984. A unique magnesiochloritoid-bearing, highpressure assemblage from the Monte Rosa, Western Alps: petrologic and ${ }^{40} \mathrm{Ar}-{ }^{39} \mathrm{Ar}$ radiometric study. Contributions to Mineralogy and Petrology, 87, 388-398.

Compagnoni, R., Dal Piaz, G.V., Hunziker, J.C., Gosso, G., Lombardo, B. \& Williams, P.F. 1977. The Sesia-Lanzo zone, a slice of continental crust with Alpine high-pressure low-temperature assemblages in the western Italian Alps. Rendiconti della Società Italiana di Mineralogia e Petrologia, 33, 281-334.

Coward, M.P. \& Dietrich, D. 1989. Alpine tectonics-an overview. In: Coward, M.P., Dietrich, D. \& PARK, R.G. (eds) Alpine Tectonics. Geological Society, London. Special Publications, 45, 1-29.

Dewey, J.F. 1988. Extensional collapse of orogens. Tectonics, 7, 1123-1139.

Flemings, P.B. \& Jordan, T.E. 1990. Stratigraphic modelling of foreland basins: Interpreting thrust deformation and lithosphere rheology. Geology, 18, 430-434.

Freeman, S.R., Butler, R.W.H., Cliff, R.A., Inger, S. \& Barnicoat, A.C. 1998. Deformation migration in an orogen-scale shear zone array: and example from the Basal Briançonnais Thrust, internal Franco-Italian Alps. Geological Magazine, 135, 349-367.

Hacker, B.R., Ratschbacher, L., Webb, L., McWilliams, M.O., Ireland, T., Calvert, A., Dong, S.W., Wenk, H.R. \& Chateigner, D. 2000. Exhum- ation of ultrahigh-pressure continental crust in east central China: Late Triassic-Early Jurassic tectonic unroofing. Journal of Geophysical Research-Solid Earth, 105, 13339-13364.

Inger, S., Ramsbotham, W., Cliff, R.A. \& Rex, D.C. 1996. Metamorphic evolution of the Sesia-Lanzo zone, Western Alps: Time constraints forum multi-system geochronology. Contributions to Mineralogy and Petrology, 126, 152-168.

Lemoine, M. \& TrümPy, R. 1987. Pre-oceanic rifting in the Alps. Tectonophysics, 133, 305-320.

Molnar, P. \& Lyon-CAEn, H. 1988. Some simple physical aspects of the support, structure and evolution of mountain belts. In: CLARK, S.P., Burchriel, B.C. \& Suppe, J. (eds) Processes in Continental Lithospheric Deformation. Geological Society of America Special Publications, 179-207.

Mosar, J., Stampfli, G.M. \& Girod, F. 1996. Western Préalpes Médianes Romandes: timing and structure. A review. Eclogae Geologicae Helvetiae, 89, 389-425.

Pfiffner, O.A. 1986. Evolution of the north Alpine foreland basin in the Central Alps. Special Publications of the international Association of Sedimentologists, 8, 219-228.

Platt, J.P. 1987. The uplift of high-pressure low-temperature metamorphic rocks. Philosophical Transactions of the Royal Society of London, A321, 87-103.

Platt, J.P., Behrmann, J.H., Cunningham, P.C., Dewey, J.F., Helman, M., Parish, M., Shepley, M.G., Wallis, S. \& Weston, P.J. 1989. Kinematics of the Alpine arc and the motion history of Adria. Nature, 337, 158-161.

Quinlan, G.M. \& Beaumont, C. 1984. Appalachian thrusting, lithospheric flexure and the Paleozoic stratigraphy of the Eastern Interior of North America. Canadian Journal of Earth Sciences, 21, 973-996.

Reddy, S.M., Wheeler, J. \& Cliff, R.A. 1999. The Geometry and Timing of Orogenic Extension: An example from the Western Italian Alps. Journal of Metamorphic Geology, 17, 573-589.

REINECKE, T. 1991. Very-high-pressure metamorphism and uplift of coesitebearing metasediments from the Zermatt-Saas zone, Western Alps. European Journal of Mineralogy, 3, 7-17.

Royden, L.H. 1993. The tectonic expression of slab pull at continental convergent boundaries. Tectonics, 12, 303-325.

Rubatto, D., Gebauer, D. \& Fanning, M. 1998. Jurassic formation and Eocence subduction of the Zermatt-Saas-Fee ophiolites: implications for the geodynamic evolution of the Central and Western Alps. Contributions to Mineralogy and Petrology, 132, 269-287.

SinclaIR, H.D. 1992. Turbidite sedimentation during Alpine thrusting: the Taveyannaz sandstones of Eastern Switzerland. Sedimentology, 39, 837-856.

SINCLAIR, H.D. 1997. Tectonostratigraphic model for underfilled peripheral foreland basins: An Alpine perspective. Geological Society of America Bulletin, 109, 324-346.

Sinclair, H.D. \& Allen, P.A. 1992. Vertical versus horizontal motions in the Alpine orogenic wedge: stratigraphic response in the foreland basin. Basin Research, 4, 215-232.

Wheeler, J. \& Butler, R.W.H. 1993. Evidence for extension in the western Alpine orogen: the contact between the oceanic Piemonte and overlying continental Sesia units. Earth and Planetary Science Letters, 117, 457-474.

WheEler, J. \& Butler, R.W.H. 1994. Criteria for identifying structures related to true crustal extension in orogens. Journal of Structural Geology, 16, 1023-1027. 